\title{
DEVELOPMENT DESPITE MODEST GROWTH IN THE MIDDLE EAST
}

\author{
Syed Mansoob Murshed ${ }^{*}$ \\ The Birmingham Business School \\ University of Birmingham \\ University House, Edgbaston, Birmingham B15 2TT, UK. \\ Institute of Social Studies (ISS), PO Box 29776 \\ 2502 LT, The Hague, The Netherlands. \\ Centre for the Study of Civil War (CSCW) \\ PRIO, Oslo, Norway. \\ Murshed@iss.nl \\ $21^{\text {st }}$ December 2008
}

\begin{abstract}
The Middle Eastern region is a major supplier of the world's energy. It is also characterised by conflict, and is the focus of global geo-political interest both because of oil and the volatile nature of disputes in the region, which are perceived to have far reaching global security implications. Would we expect such a region to prosper? On the one hand, the answer should be affirmative on account of natural resource wealth, but on the other hand it could be negative due to the presence of conflict and the potential resource rent mismanagement. The actual record is somewhere in the middle. I argue that the region has made substantial progress in human development in spite of modest growth rates, which is related to the region's cultural heritage with a low tolerance for poverty and inequality. Its outcome based institutional development is not unimpressive, which bodes well for long-term growth prospects. Additionally, recent oil rents have not been mismanaged. More, however, needs to be done to foster economic diversification and diminish dependence on natural resources.
\end{abstract}

\section{J.E.L Classification Numbers: O11, 053}

Keywords: Economic Development, Human Development, Middle East

\footnotetext{
* An earlier, and longer, version of this paper (Murshed, 2007) was prepared for the United Nations Economic and Social Council for West Asia (ESCWA). I would like to thank Ghassan Dibeh, the editor of this journal, for comments; also Maimati Yasheng and Dawood Mamoon for helpful research assistance.
} 


\section{Introduction}

The broadly defined Middle East; inclusive of Iran, North Africa and Central Asia, is home to about two-thirds of the world's known oil reserves and about half of its natural gas reserves. The region is thus a major supplier of the world's energy. It is also characterised by conflict in Palestine, Lebanon and Iraq, and is the focus of global geo-political interest both because of oil and the volatile nature of disputes in the region, which are perceived to have far reaching global security implications. Other things being equal, do we expect such a region to prosper? On the one hand, the answer must be in the affirmative on account of its natural resource wealth, but on the other hand it could be in the negative due to the presence of conflict and the potential mismanagement of resource rents. As always, the true answer and economic record of the region is somewhere in the middle. I argue that the region has made substantial progress in human development in spite of modest growth rates. This may be related to the region's cultural heritage, which fosters a comparatively lower tolerance for poverty and inequality. Its institutional development is not unimpressive, which bodes well for its long-term growth prospects. Moreover, there is little evidence that the recent oil rents have been squandered. Much more, however, needs to be done to foster economic diversification and diminish dependence on natural resources if longterm growth is to be promoted. The organisation of the paper is as follows. Section 2 is concerned with macroeconomic growth issues relevant to the region, followed by developments in poverty, inequality, human and institutional development in section 3. Section 4 analyses the current oil boom in the region. Finally, section 5 concludes by considering domestic constraints to growth.

\section{Economic Performance in the West Asian Region}

There are two economic definitions for the region. ESCWA (Economic and Social Commission for West Asia, a United Nations organisation) extends from Iraq to Egypt, taking in the Gulf and the Arabian Peninsula. The World Bank utilises a larger grouping for this region, known as MENA (Middle East and North Africa) including additionally Comoros, Djibouti, Iran, Libya and the countries of the Maghreb (Algeria, Morocco and Tunisia). In turn the Bank's regional definition is made up of three categories of economies; see World Bank (2006). The first is described as resource poor labour abundant consisting of Djibouti, Egypt, Jordan, Lebanon, Morocco and Tunisia. The second country category is called resource rich and labour abundant including Algeria, Iran, Iraq, Syria and Yemen. The third group is named resource abundant and labour importing comprising Bahrain, Kuwait, Oman, Qatar, Saudi Arabia and the UAE, corresponding to the Gulf cooperation council (GCC) countries. The IMF (2006) 
has a more broad definition which includes Central Asian countries as well as Afghanistan and Pakistan. Table 1 presents annual average growth rates in real GDP per-capita, decade upon decade, since 1960 for MENA countries, as and when data is available.

The economies of the region are certainly not homogenous. The GCC countries, major oil exporters, are (or have been) high income countries, they are undiversified as oil accounts for a high proportion of their national income. Most of the other countries in the region are (lower) middle income nations, except Yemen and Djibouti which are low-income countries. The growth performance of the region since 1980 has lagged behind dynamic East Asia, and also South Asia. There is also some evidence that growth in the MENA region is more subject to volatility than in other parts of the world (Makdisi, Fattah and Limam, 2000). Most nations in the region appeared to have grown reasonably well in the 1960s and the 1970s, along with other developing countries. The 1980s represent the worst decade as far as growth in real per-capita income is concerned, a feature shared with Latin America and sub-Saharan Africa, but generally the MENA region as a whole has been ahead of these two other developing regions. The growth rate for the region is below that of the developing world average for the 1980 to 2000 period. All of the oil exporting or resource rich countries, except Oman, experienced negative growth. Growth also slowed down elsewhere in the region. But, this feature is shared with the rest of the developing world in the 1980s; see Murshed (2004). Major oil exporters (resource rich labour importing countries) continued to experience negative growth in the 1990s, although it was less pronounced than in 1980s when oil prices initially plummeted. Other nations recovered, and that recovery gathered momentum with the new millennium. Even the major oil exporters started to enter positive growth territory, as oil prices started to increase from 1998, and positive growth rates appeared among the major resource rich countries even before the major spike in oil prices in 2004.

It is useful to distinguish between three types of factors that impact on growth performance ranging from the short to the longer run; see Murshed (2004) for an overview. They are respectively, (a) short-term macroeconomic policy encompassing inflation (monetary policy), exchange rate volatility (monetary policy), terms of trade fluctuations (purely exogenous and not a policy variable) and the size of government expenditure (fiscal policy); (b) more structural factors, including the trade policy stance, the size of external and internal debt, financial deepening and the productivity of capital (which may depend on infrastructure and skills accumulation); (c) the role of institutions, covering the polity and quality of governance. The first two determine the proximate causes of growth: investment in physical and capital, factor accumulation, and their productivity. The last factor constitutes the deep determinant of growth; without the right institutional setting investment will not take place (for example, if the risk of 
appropriation is high), and the right policies will never be adopted (in a factional state, for instance, only the interests of certain groups will be served).

Table 1: Annual Average Growth of Real Per Capita GDP (\%)

Constant 2000 USD

\begin{tabular}{l|c|c|c|c|c|c}
\hline COUNTRY & $\begin{array}{l}1961- \\
1970\end{array}$ & $\begin{array}{l}1971- \\
1980\end{array}$ & $\begin{array}{l}1981- \\
1990\end{array}$ & $\begin{array}{l}1991- \\
2000\end{array}$ & $\begin{array}{l}2001- \\
2004\end{array}$ & $2001-$ \\
\hline Algeria & 2.8 & 4.6 & -0.2 & -0.2 & 3.3 & 3.4 \\
\hline Bahrain & & & -1.8 & 2.4 & 3.9 & 4.2 \\
\hline Comoros & & & 0.3 & -0.9 & 0.3 & 0.6 \\
\hline Djibouti & & & & -4.2 & 0.7 & 0.8 \\
\hline Egypt & 2.7 & 4.5 & 3.0 & 2.4 & 1.5 & 1.8 \\
\hline Iran & & & -0.9 & 2.2 & 4.4 & 4.1 \\
\hline Jordan & & & -1.6 & 0.9 & 3.4 & 3.7 \\
\hline Kuwait & & -7.6 & & -1.9 & 3.3 & 3.7 \\
\hline Lebanon & & & -1.7 & 5.3 & 3.4 & 2.7 \\
\hline Libya & 15.9 & -1.6 & & & & \\
\hline Mauritania & 4.3 & -0.8 & -0.6 & 0.3 & 0.6 & 0.9 \\
\hline Morocco & 2.7 & 2.5 & 1.7 & 0.9 & 3.0 & 2.5 \\
\hline Oman & 14.9 & 1.1 & 4.5 & 1.7 & 2.5 & \\
\hline Saudi Arabia & & 6.6 & -5.6 & 0.0 & 0.6 & 1.3 \\
\hline Sudan & -0.6 & 0.5 & -0.002 & 3.3 & 3.8 & 4.2 \\
\hline Syria & 1.2 & 6.0 & -1.2 & 2.4 & 1.1 & 1.4 \\
\hline Tunisia & 2.8 & 4.5 & 1.2 & 3.1 & 3.6 & 3.5 \\
\hline Turkey & & 1.5 & 2.3 & 1.8 & 2.5 & 3.2 \\
\hline United Arab Emirates & & & -4.8 & -1.8 & 0.6 & 1.5 \\
\hline Yemen & & & 0 & 1.5 & 0.3 & 0.1 \\
\hline MENA & & & 0.5 & 1.7 & 2.2 & 2.3 \\
\hline $\begin{array}{l}\text { Latin America and } \\
\text { the Caribbean }\end{array}$ & & & -0.7 & 1.7 & 0.6 & 1.1 \\
\hline South Asia & & & 3.4 & 3.3 & 4.2 & 4.8 \\
\hline East Asia and Pacific & & & 5.9 & 7.3 & 7.3 & 7.5 \\
\hline Sub-Saharan Africa & & & -0.9 & -0.4 & 1.6 & 1.9 \\
\hline \multicolumn{1}{|c|}{} & & & & & \\
\hline
\end{tabular}

Source: World Bank, WDI 2006

Short-run macroeconomic policies that cause inflation, or distort the nominal exchange rate, may deter investment and growth. Real exchange rate appreciation is common with Dutch Disease type phenomenon ${ }^{1}$ (natural resource

${ }^{1}$ The Dutch Disease effect refers to a natural resource boom, which contracts the economy's traded sector relative to its non-traded sector. The mechanism is a rise in the relative price of nontraded goods and real exchange rate appreciation. This is known as the resource re-allocation effect. It is also accompanied by an increase in aggregate private and public spending. 
rent booms), and are the crucial mechanism in crowding out traditional exports by making their prices abroad more expensive, as discussed in Murshed (2004) Fiscal deficits (depending on government consumption relative to revenues) can be inflationary when monetised; they can also exert an adverse effect on growth if the government's borrowing from the private sector crowds out private investment. A large public sector may also be symptomatic of Dutch Disease in oil exporting economies, reflecting the switch in output towards non-traded goods and services. General government consumption can also retard growth, if the taxes levied to cover public spending are distortionary.

In the more medium-term there are number of structural reforms to consider, which may aid growth. These include the trade policy stance, and how open the economy is, because buoyant exports (especially of manufactured goods whose demand is income elastic) can act as a spur towards general growth. Here we have to carefully distinguish between outcomes (the measured share of international trade in GDP) and policies which gauge the restrictiveness of the trade regime. The latter is clearly more important for growth. Most oil-rich GCC countries maintain a very open trade policy stance; other more diversified economies (such as Syria, Egypt and the Maghreb countries) have had more protective trade policies. Unsustainable internal and/or external debt stocks can also hamper growth, due to the burden of debt servicing which may divert resources away from growth promoting activities. The degree to which financial liberalisation is permitted determines first the degree of financial intermediation, and ultimately the supply of credit to the private sector. This is most important, both for harnessing savings, and also for the process of directing these into productive investment. In this connection, rigid state control of commercial banks may hinder financial deepening, and the supply of credit for investment; but equally hasty financial liberalisation without adequate prudential regulation can cause financial and exchange rate crises when things go wrong, as was evident in East Asia during 1997, particularly in Indonesia. There are various factors that can promote the productivity of capital, usually measured as total factor productivity. These include the presence of infrastructure such as roads and telecommunications, but also human development measured in terms of both health and education outcomes, as well as the quality of institutions.

In the final analysis we have the impact of institutions in determining long-term growth rates. This has been emphasised, for example, by Acemoglu, Robinson and Johnson (2005). Institutions of importance mainly relate to governance measures (including those that facilitate or hinder private enterprise), but the overall polity (quality of democracy) may be also be important. So, how does the region fare in terms of various indicators; secondly, what are their relative values as drivers of growth in the region. 
Starting off with inflation, Hakura (2004) points out that inflation in the MENA region was about the same as in the high growth East Asian economies, and usually below the 7-11\% danger zone identified by the IMF. Furthermore, in Hakura's cross-sectional regression of growth determinants in the 1980 to 2000 period, covering 10 MENA countries (including major oil exporting GCC economies), as well as nations outside the MENA region for the purposes of comparison, the negative contribution of inflation is present but statistically insignificant. With regard to the negative effects of real exchange rate overvaluation, Hakura (2004) finds that it has a small and significantly negative impact on growth, except when the oil rich GCC countries are excluded. This, points to some evidence of Dutch Disease type effects due to the oil booms of the 1970s lingering in GCC countries. Similarly, the ratio of government consumption to GDP retards growth, except during the 1990s, and when the presence of conflict is taken into account. This suggests that conflict puts upward pressure on government spending, with negative growth effects. Volatility in the terms of trade has little explanatory power in determining growth in the sample of countries considered. No control, however, is present for the special effects of MENA (or MENA oil) region is made in the regressions in this study.

The study by Nabli and Véganzonès-Varoudakis (2007) of the determinants of growth (1980-2000) in the MENA region and other countries does not incorporate the major Gulf oil exporters. It, however, has innovative properties, including the use of principal components analysis to identify and rank the chief determinants of growth. They develop a hybrid concept of macroeconomic stability comprising inflation, the public sector budget deficit, and the presence or absence of black market premia in the foreign exchange market. The overall position regarding macroeconomic stability improved in the 1990s, compared to the 1980s when they were growth retarding effects on all three counts in Iran, Syria and Algeria. Problems are said to remain in Iran, Algeria and Syria with regard to the black market premium on foreign exchange, along with inflation in Iran, Algeria, Egypt and Syria, and budget deficits in Tunisia and Morocco. The study has a separate explanatory variable for growth described as external stability composed of two components, the debt stock as a proportion of GDP and the current account of the balance of payments as a percentage of exports of goods and services. This was a major issue in MENA countries from the 1980s, and may have cost the MENA countries studied in Nabli and Véganzonès-Varoudakis (2007) about 1\% of percapita GDP growth per annum in the 1980 to 2000 period. All in all, their principal components analysis of growth determinants suggests that internal and external macroeconomic problems may have cost these MENA countries annually $-2.2 \%$ of GDP per capita between 1980 to 1989, but after reforms they may have contributed $1.4 \%$ per year to growth during the 1990 s. 
Table 2 illustrates patterns of government consumption as a proportion of GDP between 1970 and 2005. The region is characterised by large government spending as a proportion of national income. This figure size is quite resilient in the oil economies of the region, whereas it has been declining in recent years in the more diversified countries without conflict such as Egypt and Jordan, as well as Algeria, clearly following the structural reforms mentioned above.

Table 2: General government final consumption expenditure (\% of GDP)

\begin{tabular}{|c|c|c|c|c|c|c|c|c|}
\hline & 1970 & 1975 & 1980 & 1985 & 1990 & 1995 & 2000 & 2005 \\
\hline Algeria & 16.5 & 14.4 & 15.2 & 16.7 & 16.1 & 16.8 & 14.1 & 7.2 \\
\hline Bahrain &.. &.. & 13.0 & 22.8 & 24.2 & 20.8 & 17.6 & .. \\
\hline Egypt & 24.7 & 24.9 & 15.7 & 17.2 & 11.3 & 10.5 & 10.9 & 12.7 \\
\hline Iran & .. & 24.2 & 20.8 & 15.5 & 11.1 & 12.0 & 13.9 & 13.5 \\
\hline Jordan &.. & .. & 28.8 & 26.3 & 24.9 & 17.1 & 17.0 & 16.0 \\
\hline Kuwait & 13.6 & 11.1 & 11.2 & 22.4 & 38.7 & 32.2 & 21.5 & .. \\
\hline Lebanon &.. &.. & .. &.. & 24.6 & 9.8 & 17.6 & 15.2 \\
\hline Libya & 18.2 & 27.6 & 21.8 &.. & 24.4 & 22.3 & 20.5 &.. \\
\hline Oman & 12.8 & 31.6 & 25.0 & 27.1 & 22.3 & 25.1 & 20.7 & .. \\
\hline Saudi Arabia & 17.0 & 14.6 & 15.9 & 31.9 & 29.2 & 23.6 & 26.0 & 23.1 \\
\hline Syria & 17.5 & 21.1 & 23.2 & 23.8 & 14.3 & 13.4 & 11.2 & ... \\
\hline Tunisia & 16.9 & 14.6 & 14.5 & 17.0 & 16.4 & 16.9 & 15.6 & 14.4 \\
\hline $\begin{array}{l}\text { United Arab } \\
\text { Emirates }\end{array}$ & .. & 8.3 & 10.9 & 19.6 & 16.3 & 16.4 & 15.4 & .. \\
\hline $\begin{array}{l}\text { West Bank and } \\
\text { Gaza }\end{array}$ & .. & .. & .. & .. & .. & 18.9 & 37.4 & .. \\
\hline Yemen & ... & .. & .. & ... & 17.5 & 14.4 & 12.7 & 12.9 \\
\hline $\begin{array}{l}\text { East Asia \& } \\
\text { Pacific }\end{array}$ & 8.6 & 8.6 & 13.9 & 12.9 & 11.7 & 10.7 & 11.2 & .. \\
\hline $\begin{array}{l}\text { Sub-Saharan } \\
\text { Africa }\end{array}$ & 12.9 & 14.6 & 14.7 & 16.5 & 17.4 & 15.3 & 16.0 & 17.3 \\
\hline $\begin{array}{l}\text { Latin America \& } \\
\text { Caribbean }\end{array}$ & 10.0 & 11.1 & 10.3 & 10.3 & 11.6 & 14.0 & 14.8 & 13.2 \\
\hline MENA & .. & 22.3 & 18.8 & 17.5 & 15.0 & 14.4 & 14.9 & 13.2 \\
\hline
\end{tabular}

Source: World Bank, WDI 2006

Table 3 gives us a picture of the evolution of the external debt stock and the total stock of domestic government debt respectively. MENA external indebtedness is below the levels of most low-income African economies, but higher than several East Asian economies. It has to be borne in mind that Egypt benefited from external debt forgiveness after the 1991 Gulf War, similar to Mexico and Poland during the late 1980s. The external debt position of Egypt has worsened recently due to balance of payments problems. In most MENA countries external debt rose during the 1980s and early 1990s, but declined afterwards. These stocks are still high in the Lebanon, Jordan, Syria and Tunisia. 
As far as government debt is concerned (Table 4), it is interesting to note that the recent oil boom has led to the reduction of total government debt in most GCC oil rich countries except Bahrain, mitigating any potential Dutch Disease effects of the recent oil booms. The more diversified economies, however, have not improved their government indebtedness positions, except for Jordan from a highly adverse position. The level of government debt is of concern in Syria, Jordan, Morocco and Tunisia, as it is above or near the $60 \%$ level of GDP considered imprudent under the Maastricht criterion for European monetary union. Egypt has very high and unsustainable government debt that is well above $100 \%$ of GDP, as has Lebanon where the level of government debt before the 2006 Israeli invasion was at a staggering and unsustainable 175\% of GDP.

In the oil rich GCC sub-region, Auty (2001) points to three factors that may have caused the growth collapse of the 1980s and early 1990s, especially in Saudi Arabia. First, there was an overestimation of the economy's ability to absorb the huge oil rents compared to per-capita GDP. Granted a great deal was saved and invested abroad, but excessive amounts of the oil rents were invested unproductively, more than would be warranted by economic size. Secondly, the real exchange rate appreciation following the 1970s oil booms was allowed to persist even after the decline in oil prices in the early 1980s. This may have exacerbated 'Dutch Disease' type effects. Thirdly, and perhaps most importantly, there was fiscal imprudence along with a bloated public sector, which led to cumulatively increasing indebtedness in Saudi Arabia and elsewhere. According to Hakura (2004) this factor, along with high initial per-capita incomes in 1980 are the main reasons behind the poor growth performance of GCC countries. Taken together, these two phenomena are symptoms of the spending and resource re-allocation effects of Dutch Disease. These factors can be said to have hindered economic diversification and competitive industrialisation in the Gulf. Balanced against these policy errors, are the positive policy choices to do with the fact that most GCC countries continue to remain very open economies, and either invested their oil surpluses in overseas financial markets and/or for the development of domestic infrastructure and human capital. Eifert, Gelb and Tallroth (2002), as well as Auty and Gelb (2001) discuss the special 'paternalistic' political economy of the Gulf oil rich countries, which make it difficult to curtail public expenditure and the size of the public sector without potentially jeopardising the unique societal stability that characterises these countries. The growth retarding effects of a large government consumption share in GDP have to be contrasted with the positive effect of public sector employment and expenditure on social harmony and conflict prevention. 
Table 3: External Debt Stocks as a \% of GDP (current US\$)

\begin{tabular}{l|r|r|r|r|r|r}
\hline COUNTRY & 1980 & 1985 & 1990 & 1995 & 2000 & 2004 \\
\hline Algeria & 46 & 32 & 45 & 79 & 47 & 26 \\
\hline Egypt & 83 & 104 & 77 & 56 & 29 & 38 \\
\hline Iran & 5 & 3 & 7 & 23 & 8 & 8 \\
\hline Jordan & 47 & 77 & 207 & 114 & 87 & 71 \\
\hline Lebanon & & & 63 & 27 & 59 & 101 \\
\hline Morocco & 52 & 125 & 97 & 72 & 62 & 35 \\
\hline Oman & 10 & 23 & 23 & 42 & 33 & 16 \\
\hline Saudi Arabia & & & & & 16.1 & 11.0 \\
\hline Sudan & 68 & 72 & 112 & 245 & 133 & 89 \\
\hline Syria & 27 & 66 & 140 & 188 & 120 & 86 \\
\hline Tunisia & 40 & 58 & 63 & 60 & 58 & 66 \\
\hline Yemen & & & 132 & 147 & 54 & 43 \\
\hline MENA & $\mathbf{2 9}$ & $\mathbf{3 4}$ & $\mathbf{5 0}$ & $\mathbf{5 0}$ & $\mathbf{3 2}$ & $\mathbf{3 0}$ \\
\hline Sources: WordBank WDi
\end{tabular}

Sources: World Bank, WDI 2006; IMF (2006)

\begin{tabular}{|c|c|c|c|c|}
\hline \multicolumn{5}{|c|}{ Table 4: Government Debt Stocks (\% of GDP) } \\
\hline COUNTRY & 1990 & 1995 & 2000 & 2005 \\
\hline Algeria &.. & 99.6 & 63.6 & 28.5 \\
\hline Bahrain & 8.7 & 17.0 & 29.3 & 30.3 \\
\hline Egypt & & & 82.0 & 112.5 \\
\hline Iran & & & 28.3 & 17.4 \\
\hline Jordan & 133.3 & 105.1 & 93.7 & 84.7 \\
\hline Kuwait & & & 40.0 & 13.1 \\
\hline Libya & & & 33.7 & 1.2 \\
\hline Lebanon & .. & 78.5 & 144.8 & 174.6 \\
\hline Morocco & 102.1 & 80.7 & 77.8 & 70.5 \\
\hline Oman & 19.6 & 27.4 & 19.1 & 10.8 \\
\hline Qatar & & & 59.9 & 30.5 \\
\hline Saudi Arabia & & & 96.7 & 39.6 \\
\hline Syria & & & 62.9 & 60.2 \\
\hline Tunisia & 54.8 & 57.7 & 62.6 & 55.9 \\
\hline MENA average & & & 64.8 & 45.9 \\
\hline
\end{tabular}

Notes: (a) 2000 figures for Egypt, Iran, Kuwait, Libya, Lebanon, Morocco, Qatar Saudi Arabia, Syria, United Arab Emirates and the MENA region are the average for 19982002; (b) Data for Egypt, Jordan, Syria and Tunisia refer to general government.

Sources: World Bank WDI 2006, IMF (2006)

Reverting back to the non-GCC countries of the region, Nabli and Véganzonès-Varoudakis (2007) find that structural reforms (open trade policies, financial liberalisation and so on) do not yield growth dividends unless preceded, or 
accompanied, by measures to promote macroeconomic stability. In contrast, macroeconomic adjustment, even in the absence of structural reforms, yields some growth dividends. With regard to the openness, Hakura (2004) does not find the total trade to GDP ratio significantly affects growth. But that is an outcome measure. Using the Sachs and Warner (1995) measures of openness, Makdisi, Fattah and Limam (2000) find that it is significant in explaining growth in a cross section of countries including MENA countries, but as is now well known, these variables could be picking up effects of institutional quality.

Hakura (2004) points out that human capital endowments measured by secondary school enrolment were high in the region by developing country standards, so it cannot be a major growth retarding factor in the MENA region. ${ }^{2}$ According to Nabli and Véganzonès-Varoudakis (2007), human development and infrastructure exert about an equally important effect in growth generation in the region. The combined role of human development and infrastructure (roads and telecommunications), along with structural reforms was about 2.7\% during 1980-89, and $2.1 \%$ in 1990-99, according to their growth decomposition and principal component analysis.

The savings rates in the MENA region are not below those for many other developing countries outside Asia (Murshed, 2007). What matters is the productivity of investment. Indeed, Sala-i-Martin and Artadi (2002) point out that the investment rate is not always robustly correlated with growth. High investment rates may mask a great deal of public investment, in addition to that from private sources. Public investment in infrastructure may be growth enhancing, but the financing of this expenditure could have distortionary and negative effects on growth. The productivity of investment depends to a great extent on the presence of complementary factors such as skilled labour and infrastructure, as indicated in the work of Nabli and Véganzonès-Varoudakis (2007). Furthermore, Sala-i-Martin and Artadi (2002) indicate that despite the fact that secondary enrolment has been high in the MENA region its quality may leave much to be desired. Growth can take place due to the accumulation of factors of production (capital and labour), something referred to as extensive growth, and/or due to the augmentation of the productivity of these factors of production over time (intensive growth). The latter is measured by a variable known as total factor productivity (TFP) growth. ESCWA (2005), reports that only five MENA countries, Egypt, Oman, Morocco, Syria and Tunisia registered positive TFP growth in the 1980-2000 period.

${ }^{2}$ In empirical growth analysis countries starting out with higher human capital (skills and education) in the initial year of the growth period under scrutiny usually enjoy higher growth rates. 


\section{Human and Institutional Development}

Table 5 provides us with an overview of the current state of human development in the MENA, drawn from the UNDP's (2006) human development report. The cornerstone of this approach is the human development index, which is an unweighted or equal weighted average of income per-capita adjusted for the cost of living, longevity (including child and maternal mortality rates) and educational status (a hybrid of adult literacy and tiered educational enrolment). I also present data on the annual average growth in per-capita income and the GINI coefficient of income inequality where data is available, along with a measure of educational achievement and life expectancy at birth. MENA countries fare moderately well in human development. The HDI rankings of countries in the Gulf (particularly in Saudi Arabia) are bound to rise when growth rejuvenates, and if there are further improvements in the education index, which will imply catching up to the levels of richer East Asian countries such as Singapore and South Korea. Data on inequality are not available for GCC countries, where it is reasonable to assume that abject income poverty does not exist. The more diversified economies in the region do well in terms of measured inequality, as many as are egalitarian as countries in East and South Asia. Also, achievements in terms of education, longevity and reducing health inequalities are impressive (Murshed, 2007).

Table 5: Human Development Indicators for Selected Countries in 2006

\begin{tabular}{|l|l|l|l|l|l|}
\hline COUNTRY & $\begin{array}{l}\text { HDI } \\
\text { rank }\end{array}$ & $\begin{array}{l}\text { Annual \% } \\
\text { growth of per- } \\
\text { capita income: } \\
\mathbf{1 9 7 5 - 2 0 0 4}\end{array}$ & $\begin{array}{l}\text { GINI } \\
\mathbf{( 2 0 0 6 )}\end{array}$ & $\begin{array}{l}\text { Education } \\
\text { Index }\end{array}$ & $\begin{array}{l}\text { Life } \\
\text { Expectancy } \\
\text { at birth } \\
\text { (2000-05) }\end{array}$ \\
\hline Kuwait & 33 & -0.8 & --- & 0.87 & 76.8 \\
\hline Qatar & 46 & --- & --- & 0.85 & 72.7 \\
\hline UAE & 49 & -2.8 & --- & 0.71 & 77.9 \\
\hline Libya & 64 & --- & --- & 0.86 & 73.4 \\
\hline Saudi Arabia & 76 & -2.3 & --- & 0.72 & 71.6 \\
\hline Jordan & 86 & 0.5 & 38.8 & 0.86 & 71.2 \\
\hline Tunisia & 87 & 2.3 & 39.8 & 0.75 & 73.1 \\
\hline Iran & 96 & -0.1 & 43.0 & 0.75 & 70.2 \\
\hline West Bank \& Gaza & 100 & --- & --- & 0.89 & 72.4 \\
\hline Syria & 107 & 1.1 & & & 73.2 \\
\hline Egypt & 111 & 2.6 & --- & 0.74 & 69.6 \\
\hline Morocco & 123 & 1.4 & 34.4 & 0.73 & 69.5 \\
\hline Yemen & 150 & --- & 39.5 & 0.54 & 60.3 \\
\hline
\end{tabular}

Notes: HDI rank goes from 1-177, with 1 as the highest, and 177 as the lowest. GINI ranges from 0 to 100; 0 implying no inequality and 100 the most unequal.

The education index is a combination of adult literacy, as well as the combined primary, secondary and tertiary gross enrolment ratios.

Sources: UNDP (2006), and World Bank, WDI (2006). 


\section{Poverty and Inequality}

We have seen that growth has been modest in the region, and even negative for the GCC countries, in the 1980 to 2000 period. Growth is only one component of the overall picture of human development. A fuller description requires us also to consider developments in the incidence of poverty, and the evolving pattern of income inequality. Indeed, it is in terms of poverty that the region's performance has been the most impressive in the developing world. Table 6 confirms that the region has the lowest incidence of abject poverty based upon the international comparison of US $\$ 1$ a day per person in purchasing power parity terms (PPP). ${ }^{3}$ True, East and South Asian nations have made large strides in poverty reduction, but MENA countries ${ }^{4}$ have also continued to maintain their low poverty incidence despite very modest growth rates in the two decades following 1980.

Table 6: Regional Poverty and Inequality Trends

\begin{tabular}{|l|l|l|l|l|l|l|l|l|l|}
\hline Region & \multicolumn{2}{l}{$\begin{array}{l}\text { Poverty head count } \\
\text { as a \% of the population: } \\
\text { PPP \$1 day }\end{array}$} & \multicolumn{3}{l|}{ GINI } & \multicolumn{3}{l|}{$\begin{array}{l}\text { Income share } \\
\text { Poorest Quintile }\end{array}$} \\
\hline & $\begin{array}{l}\text { Average } \\
1980 \text { s }\end{array}$ & $\begin{array}{l}\text { Average } \\
1990 \text { s }\end{array}$ & $\begin{array}{l}\% \\
\text { Change }\end{array}$ & $\begin{array}{l}\text { Average } \\
1980 \text { s }\end{array}$ & $\begin{array}{l}\text { Average } \\
1990 \text { s }\end{array}$ & $\begin{array}{l}\% \\
\text { Change }\end{array}$ & $\begin{array}{l}\text { Average } \\
1980 \text { s }\end{array}$ & $\begin{array}{l}\text { Average } \\
1990 \text { s }\end{array}$ & $\begin{array}{l}\% \\
\text { Change }\end{array}$ \\
\hline East Asia & 23.7 & 14.9 & -37.2 & 40 & 40 & 0.2 & 6.9 & 6.4 & -7.3 \\
\hline $\begin{array}{l}\text { Latin } \\
\text { America } \\
\text { and the } \\
\text { Caribbean }\end{array}$ & 21.2 & 14.9 & -29.7 & 50 & 48 & -2.7 & 3.7 & 4.3 & 16.2 \\
\hline MENA & 1.7 & 2.0 & 17.6 & 40 & 36 & -10.1 & 6.5 & 7.5 & 15.4 \\
\hline $\begin{array}{l}\text { South } \\
\text { Asia }\end{array}$ & 36.0 & 32.9 & -8.7 & 31 & 34 & 8.0 & 8.7 & 8.4 & -3.5 \\
\hline $\begin{array}{l}\text { Sub- } \\
\text { Saharan } \\
\text { Africa }\end{array}$ & 24.6 & 42.2 & 71.5 & 41 & 45 & 8.7 & 5.8 & 5.3 & -8.7 \\
\hline
\end{tabular}

Sources: Adams and Page (2003) and WDI (2006)

Secondly, as Adams and Page (2003) point out the MENA region along with South Asia are low income inequality countries within the developing world, as measured by the GINI coefficient in table 6. Gradstein, Milanovic and Ying (2001) point out that Islamic countries are the most "intrinsically equal" after controlling for per-capita income and the political system. It also appears that MENA countries, along with Latin America, are the two regions in the developing world to have actually reduced income inequality. The reduction in inequality is,

\footnotetext{
${ }^{3}$ PPP measures are based on 1993 dollars and adjust for cost of living differences for a basket of goods across countries. An alternative measure is based on PPP \$2 a day. These two measures can be utilized for cross country differences in poverty incidence, as national poverty standards vary considerably across countries and can only be utilized in the context of that particular country.

${ }^{4}$ Poverty analysis requires data from household surveys. These are available in the MENA region in Algeria, Egypt, Iran, Jordan, Morocco, Tunisia, and to a lesser extent in Yemen.
} 
however, greater in MENA compared to Latin America. The MENA region also managed to increase the income share of the poorest quintile $(20 \%)$ of the population.

Thus, a major contrast begins to become discernable between the MENA region's experience and that of fast growing East and South Asia. In the latter, growth proceeded rapidly with a sharp decline in poverty. This was, however, accompanied with rising inequality. In the MENA countries growth was very low (practically non-existent in the 1980s), but inequality declined and poverty did not rise by much. Indeed, as pointed out by Adams and Page (2003), as well as Iqbal (2006), poverty actually fell during the growth slowdown of the 1980s, and only increased moderately thereafter. Indeed, in the famous World Bank poverty report (2001, figure 3.4), which extolled the virtues of growth being good for the poor, the MENA region was found to be the only developing world region which had falling poverty along with declining growth.

What accounts for this anomaly? Before going into the explanation for this phenomenon it is worthwhile reminding ourselves about the notions of pro-poor growth, and growth-poverty decompositions. As Kakwani and Pernia (2000), and Ravallion and Datt (1991) indicate growth influences poverty through two channels. Growth lowers poverty, as long as all incomes, including the incomes of the poor, go up as a result. Growth can raise all boats, including the poor, even if the rich benefit more from the growth. Secondly, there is an effect from the income distribution, which typically changes with growth. If growth lowers income inequality or the share of the bottom quintile of the population then poverty will decline. Kakwani and Pernia (2000) describe this as pro-poor growth. This is the growth that reduces poverty by not only raising incomes but by also altering the distribution of income in favour of the poor. By implication, nations with a lower initial inequality require a lower rate of growth to reduce poverty by a certain percentage, compared to other countries with greater initial inequality.

Adams and Page (2003) attribute the region's falling poverty even after the growth slowdown in the 1980s up to the end of that decade, to two factors: (a) the presence of worker remittances from the Gulf and Western Europe, and (b) the large share of government employment in the region (see also table 2 on government consumption). Among the less affluent nations of the region, migration to the Gulf (from Egypt and other nations in the Mashreq), and to Europe from the North African Maghreb countries kept up remittances and checked poverty. The larger than average size of government employment by developing country standards in this region also acted as a poverty alleviating cushion, and as governments re-structured or downsized in the 1990s, this avenue of insurance against poverty closed down. Iqbal (2006) has pointed out that large government size may actually increase poverty in the longer-run by retarding growth due to the distortionary effects of financing government expenditure. To 
these two factors we may add the Islamic charitable practices of zakat and sad'qa, which create private social responsibility, and have a poverty lowering impact (Sala-i-Martin and Artadi, 2002). Zakat is not insubstantial, as it amounts to 2.5\% of a person's wealth (less his dwelling) and trading income, also including percentages of agricultural income depending on harvests.

Adams and Page (2003) discover that once the level of income and inequality are controlled for the MENA region has its actual poverty level significantly below what would be predicted in a cross-country regression, which include several other non-MENA countries. Thus, the MENA region is ready for pro-poor growth because it has demonstrated this ability it in the past. In East and South Asia, growth was accompanied by rising inequality, the opposite must have occurred in the MENA region, and as has been pointed out poverty continued declining during periods of negative growth in the 1980s. In the four countries (Egypt, Jordan, Morocco and Iran) analysed by Adams and Page (2003) the redistributive aspect (improved income distribution) lowered poverty in all the countries except Morocco. In Egypt, where it is possible to get a poverty breakdown between rural and urban areas, the rise in rural poverty is mainly attributable to rising income inequality. By contrast, urban poverty and overall poverty levels declined due to increased incomes. Poverty is more prevalent in rural areas. Interestingly, female-headed households in the MENA region showed no systematic tendency to be poorer, unlike in other parts of the developing world (Iqbal, 2006). This was especially so in Egypt, where the poverty rate for femaleheaded households is lower nationally.

Table 7: Progress in Poverty Headcount Reduction by Region

\begin{tabular}{|l|l|l|l|l|}
\hline Region & $\begin{array}{l}1990 \\
(\$ 1 \text { a day })\end{array}$ & $\begin{array}{l}2002 \\
(\$ 1 \text { a day })\end{array}$ & $\begin{array}{l}1990 \\
(\$ 2 \text { a day })\end{array}$ & $\begin{array}{l}2002 \\
(\$ 2 \text { a day })\end{array}$ \\
\hline East Asia & 29.6 & 11.6 & --- & --- \\
\hline $\begin{array}{l}\text { Europe and Central } \\
\text { Asia }\end{array}$ & 0.0 & 2.1 & 4.9 & 16.1 \\
\hline LAC & 11.3 & 8.9 & 28.4 & 23.4 \\
\hline MENA & 2.3 & 1.6 & 21.4 & 19.9 \\
\hline South Asia & 41.3 & 31.2 & ---- & ---- \\
\hline Sub-Saharan Africa & 44.6 & 44.0 & ---- & ---- \\
\hline
\end{tabular}

Source: www.worldbank.org

Table 7 presents recent trends in poverty reduction in various regions of the developing world. It confirms a continuing trend of poverty reduction, and the fact that the $\$ 1$ a day poverty line is largely inapplicable to the MENA region, which has the lowest poverty rate at the $\$ 2$ a day PPP measure for any developing region outside Europe.

Iqbal (2006) points out that even when poverty reduction declined in the region during the 1990s the direction of human development improvements did 
not go into reverse, but continued improving. Controlling for initial conditions (such as initial literacy rate, life expectancy and infant mortality) the region has performed well in this regard compared to many other comparable countries in high growth East Asia. The region, despite its perceived anti-female Islamic orientation performed better in terms of female education (especially Egypt, Libya and the Yemen) compared to many countries in East Asia and Latin America (Iqbal, 2006). Demographic and health surveys have been conducted in Egypt, Jordan, Morocco and the Yemen. In Jordan, health inequalities between the rich and the poor are the lowest of the four countries surveyed. In Egypt, where two surveys have been conducted, health inequalities appear to have declined between survey periods.

\section{Institutional Quality}

Table 8: Governance indicators for selected countries in MENA region, 2005

\begin{tabular}{|c|c|c|c|c|c|c|}
\hline & $\begin{array}{l}\text { Governance } \\
\text { Indicator }\end{array}$ & Jordan & Egypt & Saudi Arabia & Syria & MENA-East Asia \\
\hline \multirow{6}{*}{$\begin{array}{l}\text { Percentile } \\
\text { Rank } \\
(\mathbf{0 - 1 0 0 )}\end{array}$} & $\begin{array}{c}\text { Voice and } \\
\text { Accountability }\end{array}$ & 27.5 & 18.4 & 4.3 & 5.8 & (24.8)-(50.8) \\
\hline & $\begin{array}{c}\text { Political } \\
\text { Stability/No } \\
\text { Violence }\end{array}$ & 35.8 & 21.2 & 26.4 & 20.3 & (35.0)-(61.3) \\
\hline & $\begin{array}{c}\text { Government } \\
\text { Effectiveness }\end{array}$ & 57.9 & 43.1 & 41.6 & 8.6 & $(45.0)-(49.6)$ \\
\hline & $\begin{array}{c}\text { Regulatory } \\
\text { Quality }\end{array}$ & 57.9 & 34.7 & 52.5 & 10.4 & $(41.8)-(46.9)$ \\
\hline & Rule of Law & 62.3 & 54.6 & 57.5 & 42.5 & (50.3)-(55.2) \\
\hline & $\begin{array}{l}\text { Control of } \\
\text { Corruption } \\
\end{array}$ & 65.5 & 43.3 & 62.6 & 36.9 & $(52.1)-(46.8)$ \\
\hline \multirow{6}{*}{$\begin{array}{l}\text { Estimate } \\
(-2.5 \text { to } \\
+2.5)\end{array}$} & $\begin{array}{c}\text { Voice and } \\
\text { Accountability }\end{array}$ & -0.74 & -1.15 & -1.72 & -1.67 & $(-0.91)-(0.04)$ \\
\hline & $\begin{array}{c}\text { Political } \\
\text { Stability/No } \\
\text { Violence } \\
\end{array}$ & -0.31 & -0.90 & -0.70 & -0.91 & $(-0.51)-(0.39)$ \\
\hline & $\begin{array}{c}\text { Government } \\
\text { Effectiveness }\end{array}$ & +0.08 & -0.35 & -0.38 & -1.23 & $(-0.21)-(-0.05)$ \\
\hline & $\begin{array}{c}\text { Regulatory } \\
\text { Quality }\end{array}$ & +0.16 & -0.47 & -0.01 & -1.22 & $(-0.28)-(0.11)$ \\
\hline & Rule of Law & +0.43 & +0.02 & +0.20 & -0.42 & $(-0.04)-(0.16)$ \\
\hline & $\begin{array}{l}\text { Control of } \\
\text { Corruption }\end{array}$ & +0.33 & -0.42 & +0.23 & -0.59 & $(-0.01)-(-0.13)$ \\
\hline
\end{tabular}

Table 8 lists the percentile ranking, as well as the actual scores of the six Kaufmann, Kraay and Mastruzzi (2006) measures of governance for various countries in the region, and the region as a whole compared to East Asia. It is well known that East Asia is the fastest growing region of the world, compared to the modest growth performance of MENA countries. But does East Asia have vastly superior governance indicators? Note that that the percentile ranking places the 
country or region's position on an international scale of $0-100$. The actual score, or estimate, ranges from -2.5 (worst) to +2.5 (best). Developed countries are included in the entire sample. What is immediately apparent is that although the region does not perform very well with regard to voice and accountability (mainly about democratic development and the infrequent or limited nature of the electoral process in the region) and political instability (reflecting regional insecurity and conflict), it does better on the control of corruption and the rule of law, where the regional position is above the world median level. Even with regard to regulatory quality and government effectiveness, arguably the most important indicators of economic governance, the region does reasonably well. Most importantly, it is not too far off East Asia's position, except in terms of voice and accountability and political instability, for obvious reasons. East Asian countries are at present more successful in their democratic transition, and the security situation is far more propitious there. In terms of control of corruption, the MENA position is superior to East Asia. Jordan's achievements with regard to the rule of law, control of corruption, regulatory quality and government effectiveness, indicators of 'hard' governance are noteworthy.

Table 9: POLITY 2, Combined Democracy-Autocracy Scores

\begin{tabular}{|c|c|c|c|c|c|}
\hline COUNTRY & 1980 & 2000 & COUNTRY & 1980 & 2000 \\
\hline Bahrain & -10 & -7 & Nigeria & 7 & 4 \\
\hline Djibouti & -8 & 2 & Oman & -10 & -9 \\
\hline Egypt & -6 & -6 & Qatar & -10 & -10 \\
\hline Ghana & 6 & 2 & Saudi Arabia & -10 & -10 \\
\hline India & 8 & 9 & South Africa & 4 & 9 \\
\hline Indonesia & -7 & 7 & Sudan & -7 & -7 \\
\hline Iran & -2 & 3 & Syria & -9 & -7 \\
\hline Iraq & -9 & -9 & Tunisia & -9 & 2 \\
\hline Jordan & -10 & -2 & Turkey & -5 & -7 \\
\hline Kenya & -6 & -2 & UAE & -8 & -8 \\
\hline Korea South & -8 & 8 & Venezuela & 9 & 3 \\
\hline Kuwait & -10 & -7 & Yemen & & -2 \\
\hline Libya & -7 & -7 & Yemen North & -6 & \\
\hline Malaysia & 4 & 3 & Yemen South & -8 & \\
\hline Mexico & -3 & 8 & & & \\
\hline
\end{tabular}

Table 9 gives us the Polity 2 score on democracy versus autocracy, which ranges from -10 (the highest autocracy score) to +10 (the maximum democracy score). 
The democratic credentials of the region are not very strong. One might be tempted to attribute this effect to Arab-Muslim culture, as many respected commentators have done, Kedourie (1992) for example. What may matter more than Islam are the oil endowments in many countries of the region. Ross (2001) finds that countries rich in oil are slower on their traverse towards democracy. The reasons he identifies are the following. There is a lack of "modernisation" as economic wealth does not translate into social and cultural change. Secondly, there is a repression effect, mineral and oil rich states can engage in higher levels of military and internal security expenditure to suppress internal dissent. Thirdly, there is a rentier effect. Revenues from oil and mineral resources create rents that can be utilised to bribe the population into silence regarding authoritarianism. Fourthly, public goods may be provided along side low taxes because resource rents are the main source of revenue for the state. Taxation normally results in pressures to introduce democractic accountability.

Two points are of importance here. First, the region exhibits a substantial degree of regime stability, compared to the rest of Asia, sub-Saharan Africa and Latin America. The literature suggests that regime instability not only enhances the risk of internal conflict (Murshed, 2006 provides a review), but it can also hamper growth. Secondly, the low democracy scores in the region are mainly attributable to the fact that elections are less frequent in the region. This does not always necessarily imply rule without consent. Many countries with imperfect and flawed electoral systems tend to do well on the Polity democracy score.

Noland's (2008a) cross country econometric study on the determinants of democracy (measured by the Polity score) does not find a robustly significant negative effect of Islam on democratic outcomes. He, however, finds that a dummy variable for the Arab population share retards democratic development, and the chances of liberalizing transitions towards democracy (Noland, 2008b). Thus, it is not Islam per se, but certain Arab characteristics that retard democratic development. Unlike Ross (2001), he finds this to be the case even after controlling for the presence of oil.

Three important caveats should, however, be borne in mind. First of all, measures like Polity are heavily biased towards process, and are not an outcome based measure of governance or human development, say. The paucity of elections and the absence of written checks and balances will lead to a low Polity score for many countries in the region. Traditional Arab consultative practices are widely unknown or misunderstood in the West. Rawls (1999) in his Law of Peoples mentions three types of societies besides liberal democracies in the following descending order of desirability: conservative systems with consultative bodies and associations, benevolent absolutisms that are respectful of human rights and outright rogue states. Western style elections may even be more frequent in rogue states; something that may secure them a higher Polity score as 
indicated above. Secondly, there are major endogeneity (reverse causality) issues connected with democracy and its exogenous determinants, such as modernization and conflict. The apparent undemocratic nature of the region could be attributed more to its geo-political salience for the West. Western interests in this region may be better guaranteed by absolutist-dynastic rule, especially in the light of the potential anti-Western policies that democracy may generate. Thirdly, Noland (2008a) points out that the lack of gender empowerment in the region may also hinder democratic transitions. There are many ways of measuring gender empowerment, such as women's participation in paid employment, and the proportion of female legislators. Ross (2008) demonstrates that Islamic culture does not retard women's participation in the labour force and in politics, but once again the presence of oil lowers women's involvement in politics and work outside the home or farm. Another, more fundamental way of looking at women's empowerment is the male-female population ratio; this according to Noland's study (2008a) promotes democracy. While the MENA region may not be viewed favourably in terms of gender rights, yet this part of the world is not notorious for 'daughter' elimination, and does not have unfavourable sex ratios as a result of these practices, unlike in many parts of India (Srinivasan and Bedi, 2008) or China. India, of course, has always had the highest Polity democracy score of any developing country. ${ }^{5}$

\section{The Recent Oil Boom}

Graph 1 illustrates trends in oil prices, which after their peak in 1980, declined until 1998, from when they picked up. Table 10 gives us the percentage decline in real oil rents (in 1990 prices) for several countries between the peak in 1980 and their decline thereafter, up to the partial recovery in 2000. Rent refers to the difference between extraction costs and the world price of oil. When this figure is multiplied with the quantity produced, the value of oil rents is arrived at. Syria, as a relatively minor exporter is the only country with an increase in the value of the real oil rent. In Saudi Arabia, the share of oil and gas rents in GNP halved from their level of 85\% in 1980 to about 43\% by 1994 (Auty, 2001, Table 12.1). ${ }^{6}$ From around 1998 the oil price has been rising, and consequently the oil rent is increasing for major producers. The recent terms of trade for Algeria, Iran, Syria, Saudi and Kuwait are plotted in graph 2, showing an improvement (fall) after 2002.

\footnotetext{
${ }^{5}$ Stewart (2008) points out that in India maternal and infant mortality rates are lower among the Muslim minority who are otherwise socio-economically and politically disadvantaged.

${ }^{6}$ In Saudi Arabia, by 2000, the real value of total oil sales declined to about $36 \%$ of their 1980 real value; own calculations based on http://www.sama.gov.sa/newreports/annual/en/section10/indexe.htm.
} 


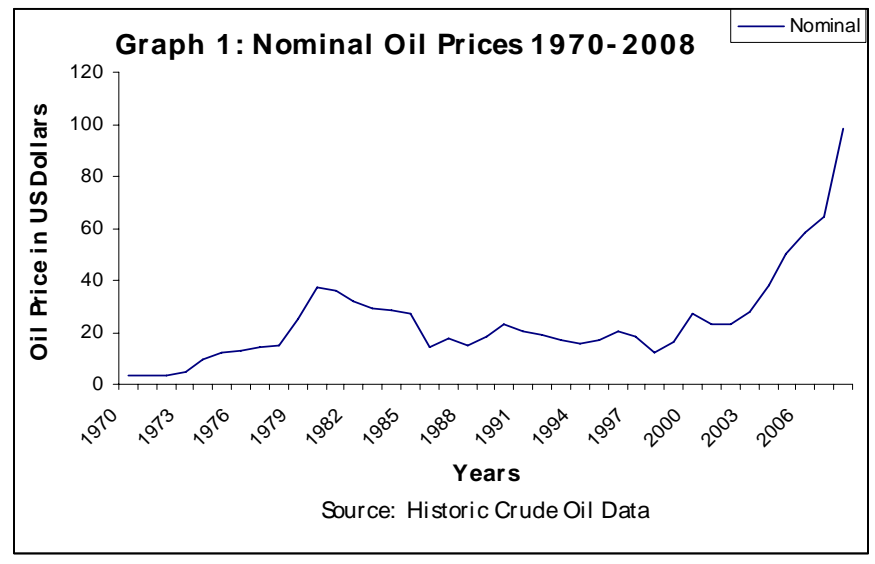

In the past, growth patterns varied greatly amongst the region's large oil producers (World Bank, 2006). After 1992, however, the business cycle in GCC countries is more coordinated and moves together. Also, there is a positive correlation between oil prices and growth for all GCC countries, and other oil exporters, Algeria, Iran, Syria and Libya. In the 1968-92 period the correlation between growth and oil prices was negative for Saudi Arabia, for Bahrain and Qatar during the 1980-92 period, and for Iran during 1968 to 1980.

Table 10: Oil rents in Constant 1990 dollars (Selected Countries)

\begin{tabular}{l|r|r|r|r}
\hline COUNTRY & \multicolumn{1}{|c|}{1980} & \multicolumn{1}{c}{1990} & \multicolumn{1}{c}{2000} & \% Change \\
\hline Algeria & $18,044,476,450$ & $4,192,000,939$ & $5,155,720,218$ & 29 \\
\hline Bahrain & $1,039,274,723$ & $300,315,639$ & $289,322,107$ & 29 \\
\hline Egypt & $10,779,635,836$ & $3,643,001,088$ & $3,081,343,135$ & 89 \\
\hline Iran & $31,319,196,688$ & $22,437,609,287$ & $27,833,043,654$ & 34 \\
\hline Iraq & $55,358,511,605$ & $13,932,966,311$ & $18,868,589,828$ & 30 \\
\hline Morocco & $5,397,052$ & $1,759,989$ & $1,641,285$ & 116 \\
\hline Syria & $3,798,186,575$ & $3,426,000,948$ & $4,391,222,798$ & 21 \\
\hline Tunisia & $2,181,332,450$ & $522,910,532$ & $456,766,950$ & \\
\hline Source: Metcalfe $(2007)$ & & & &
\end{tabular}




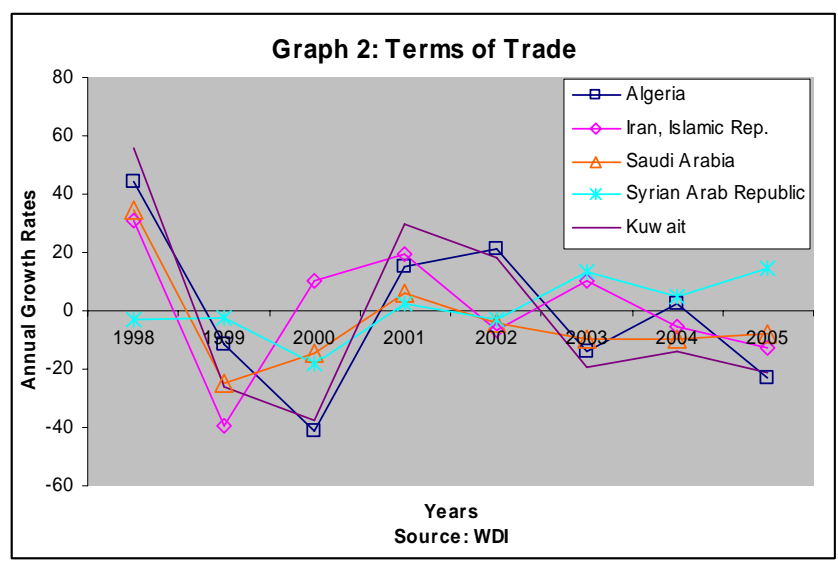

Table 11: Annual Percentage Real Oil and Non-Oil GDP Growth for MENA Oil Producers

\begin{tabular}{|l|c|c|c|c|c|c|c|c|c|c|c|c|}
\hline Country & \multicolumn{2}{|c|}{2002} & \multicolumn{2}{c|}{2003} & \multicolumn{2}{c|}{2004} & \multicolumn{2}{c|}{2005} & \multicolumn{2}{c|}{2006} & \multicolumn{2}{c|}{2007} \\
\hline & $\begin{array}{c}\text { Non- } \\
\text { Oil }\end{array}$ & Oil & $\begin{array}{c}\text { Non- } \\
\text { Oil }\end{array}$ & Oil & $\begin{array}{c}\text { Non- } \\
\text { Oil }\end{array}$ & Oil & $\begin{array}{c}\text { Non- } \\
\text { Oil }\end{array}$ & Oil & $\begin{array}{c}\text { Non- } \\
\text { Oil }\end{array}$ & $\begin{array}{c}\text { Oil } \\
\text { Non- } \\
\text { Oil }\end{array}$ & Oil \\
\hline Algeria & 5.3 & 3.7 & 6.0 & 8.8 & 6.2 & 3.3 & 4.7 & 5.8 & 5.6 & -2.5 & 6.0 & -1.0 \\
\hline Bahrain & 6.0 & 1.3 & 8.3 & 1.1 & 10.7 & - & 11.6 & -8.8 & 8.0 & -1.0 & 7.7 & -4.0 \\
\hline Iran & 7.8 & 5.1 & 6.6 & 7.7 & 5.4 & 2.9 & 5.3 & -0.4 & 6.2 & 2.7 & 7.0 & 0.9 \\
\hline Iraq & 0.2 & -13.6 & -40.2 & -42.3 & 14.9 & 74.2 & 12.0 & -8.1 & 7.5 & 5.3 & -2.0 & 4.0 \\
\hline Kuwait & 13.6 & -7.9 & 10.0 & 19.8 & 12.9 & 8.1 & 11.4 & 11.4 & 9.0 & 2.9 & 9.8 & -2.3 \\
\hline Libya & 4.7 & -0.4 & 2.5 & 26.9 & 2.6 & 5.5 & 15.8 & 7.2 & 10.7 & 4.3 & 14.7 & 1.7 \\
\hline Oman & 5.1 & -2.1 & 6.0 & -5.9 & 8.5 & -1.8 & 7.3 & 2.9 & 8.4 & 2.6 & 9.0 & -0.8 \\
\hline Qatar & 7.7 & 7.1 & 5.3 & 6.3 & 24.6 & 12.5 & 13.1 & 6.0 & 19.9 & 10.7 & 14.5 & 17.4 \\
\hline $\begin{array}{l}\text { Saudi } \\
\text { Arabia }\end{array}$ & 3.7 & -7.5 & 3.7 & 17.2 & 4.6 & 6.7 & 5.2 & 6.2 & 4.9 & -0.8 & 4.9 & 0.5 \\
\hline Syria & 3.0 & 5.8 & 3.9 & -7.3 & 5.0 & -6.1 & 6.0 & -8.6 & 6.5 & -6.4 & 5.8 & -7.3 \\
\hline UAE & 7.7 & -7.6 & 11.2 & 13.6 & 12.6 & 2.9 & 10.8 & 1.6 & 10.4 & 6.5 & 8.8 & 3.5 \\
\hline
\end{tabular}

Table 11 illustrates the recent growth in oil and non-oil GDP for oil exporting MENA countries. In all of these countries the growth in oil GDP burgeoned in 2003 except in Bahrain, Oman and Syria where the oil sector is steadily declining. In Iraq there was a huge GDP contraction due to the war, which nearly halved national income. Non-oil GDP growth was faster everywhere in 2005 (except marginally in Algeria), and this is a trend continued except in Iraq in 2007. Thus, we have some prima facie evidence for there not being Dutch Disease type production re-allocation effects during the current oil boom. Oil revenues are being saved for future use not only in GCC countries, but also in Algeria. Another gradual development, since the 1990s, is the de-coupling of the region's resource poor countries (Egypt, Jordan, Morocco, Tunisia and others) from the oil price cycle (World Bank, 2006). The reasons given for this are the reduction in the integration of the labour markets of these countries with that of the GCC countries, declining financial flows from GCC countries (although it has 
picked up recently) and rising oil bills in resource poor MENA countries, as they become richer. For Egypt the correlation between oil prices and growth became negative after 1992.

Table 12: Central Government Fiscal Balance (FB) (In percent of GDP) \& Non-Oil Fiscal Balance (NFB) (In percent of non-oil GDP)

\begin{tabular}{|c|c|c|c|c|c|c|c|c|c|c|}
\hline \multirow{2}{*}{$\begin{array}{l}\text { Countries \& } \\
\text { Regions }\end{array}$} & \multicolumn{2}{|c|}{ 1998-2002 } & \multicolumn{2}{|c|}{2003} & \multicolumn{2}{|c|}{2004} & \multicolumn{2}{|c|}{2005} & \multicolumn{2}{|c|}{2006} \\
\hline & FB & NFB & FB & NFB & FB & NFB & FB & NFB & FB & NFB \\
\hline $\begin{array}{l}\text { Middle East } \\
\text { \& Central } \\
\text { Asia }\end{array}$ & -1.6 & & 0.5 & & 2.8 & & 5.6 & & 6.2 & \\
\hline $\begin{array}{l}\text { Oil } \\
\text { exporters }\end{array}$ & 0.2 & -27.2 & 3.7 & -31.7 & 6.6 & -33.6 & 11.4 & -36.0 & 12.1 & -37.6 \\
\hline Algeria & 1.5 & -29.5 & 7.8 & -27.7 & 6.9 & -30.3 & 11.9 & -31.0 & 13.6 & -36.0 \\
\hline Bahrain & -0.6 & -25.4 & -2.0 & -33.1 & 4.6 & -29.3 & 7.6 & -28.8 & 4.7 & -28.5 \\
\hline Iran & 0.1 & -16.8 & -0.1 & -21.8 & 1.7 & -25.6 & 1.7 & -24.5 & 0.0 & -28.2 \\
\hline Iraq & & & & & -56.0 & & 6.5 & & 11.0 & -95.3 \\
\hline Kuwait & 20.5 & -39.8 & 18.0 & -47.5 & 21.2 & -48.7 & 34.1 & -39.4 & 30.7 & -48.9 \\
\hline Libya & 5.0 & -37.6 & 14.2 & -88.9 & 13.9 & -109.9 & 30.9 & -158.0 & 35.5 & -127.6 \\
\hline Oman & 3.9 & -52.1 & 5.8 & -56.6 & 4.5 & -64.9 & 12.1 & -66.5 & 14.2 & -64.9 \\
\hline Qatar & 0.8 & -50.4 & 4.3 & -47.0 & 16.4 & -42.6 & 10.8 & -61.3 & 9.2 & -41.1 \\
\hline Saudi Arabia & -4.3 & -41.9 & 1.2 & -46.7 & 10.0 & -46.5 & 18.4 & -52.3 & 21.0 & -52.7 \\
\hline Syria & -1.1 & -17.7 & -2.6 & -22.0 & -4.2 & -20.2 & -4.4 & -16.8 & -5.7 & -13.4 \\
\hline U A E & 1.6 & -32.0 & 13.8 & -28.0 & 10.2 & -21.3 & 20.0 & -17.3 & 28.6 & -14.9 \\
\hline Yemen & 0.6 & & -4.8 & & -2.2 & & -1.8 & & 1.2 & \\
\hline Egypt & -3.2 & & -9.0 & & -8.3 & & -8.4 & & -9.2 & \\
\hline Jordan & -4.5 & & -1.0 & & -1.7 & & -5.0 & & -3.8 & \\
\hline Lebanon & -17.5 & & -13.2 & & -9.7 & & -8.5 & & -10.2 & \\
\hline Morocco & -4.5 & & -4.9 & & -3.8 & & -4.8 & & -1.4 & \\
\hline Tunisia & -2.7 & & -3.1 & & -2.6 & & -3.0 & & -2.7 & \\
\hline MENA & -1.0 & & 0.7 & & 3.5 & & 7.1 & & 7.8 & \\
\hline GCC & -0.3 & & 5.5 & & 11.5 & & 19.5 & & 21.9 & \\
\hline Maghreb & -0.4 & & 3.3 & & 3.8 & & 8.4 & & 11.2 & \\
\hline
\end{tabular}


To look at the expenditure side of the recent oil boom we have to first examine patterns of government consumption and expenditure. Table 12 demonstrates that the non-oil fiscal balance for oil exporters is negative, and has grown from $-27.2 \%$ of GDP in $1998-2002$ to $-37.6 \%$ of GDP by 2005 . This is despite the fact that overall fiscal balances are in surplus, but without oil revenues a pronounced deficit would emerge. Thus, dependence on oil revenues continues unabated, although some moves have been made in Syria to reverse this process. But, on the other hand, tables 3 and 4 demonstrate that moves have been made to reduce external and government debt. For example, Saudi Arabia and Kuwait had substantially reduced their government debt from $96.7 \%$ and $40 \%$ of GDP respectively in 2000 to $39.6 \%$ and $13.1 \%$ of GDP by 2005 . The non-oil countries of the region have, however, seen their fiscal balances deteriorate (Egypt, Jordan, Lebanon, Morocco and Tunisia). This is related to higher oil prices, and the cost of domestic subsidies in this regard.

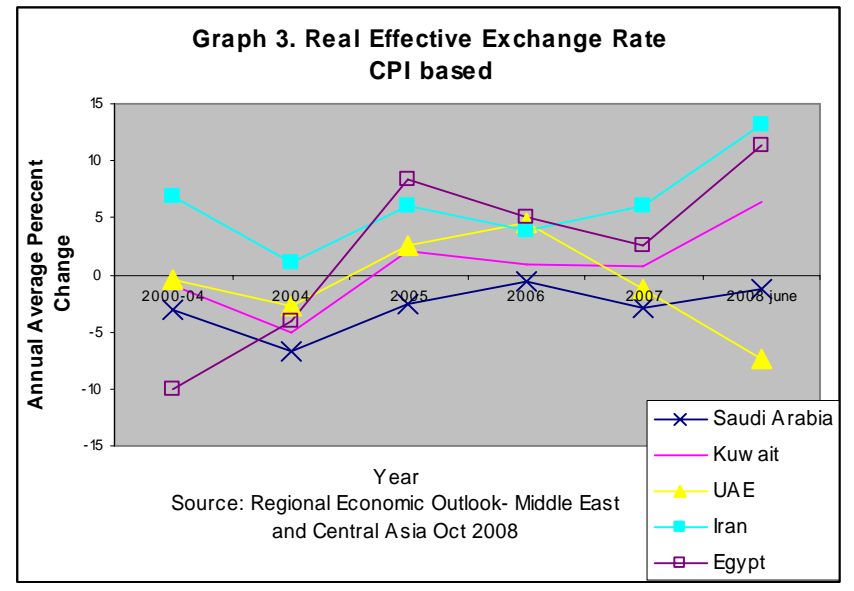

The current account of the balance of payments for non-oil countries in the region has worsened, with a substantial deficit in Jordan and Lebanon (IMF, 2006b, table 15). But most importantly, for oil exporters the real exchange rate has not been allowed to appreciate following the oil boom, this time. In fact, graph 3 illustrates a real depreciation until recently. One reason for this is that many oil exporting currencies are linked to the US dollar, which has depreciated since 2002 vis-à-vis other major currencies. Thus, another avenue of adverse macroeconomic effects of oil booms has been plugged in the region this time around, unlike during the 1980s. There has been a less pronounced increase in domestic absorption this time unlike the 1980s (see Auty, 2001 on Saudi Arabia during the 1980s), including less of an import surge (IMF, 2006b). The investment of oil surpluses has been more diversified this time around, with major 
inflows into projects in the Mashreq and Egypt (World Bank, 2006). With about two-thirds of world known oil reserves and about half of natural gas reserves in the region, its output is about a third of world oil and a fifth of gas. Steps have been taken to increase investment in oil and gas production capacity in Saudi Arabia.

There has, however, been a major expansion of domestic credit (Table 13), mainly to the private sector. This suggests Dutch Disease effects, as some of these monies are utilised to finance housing and the consumption of consumer durables. The World Bank (2006) raises three questions in this regard. First, there are still outstanding issues concerning regulation, even though the regulatory institutions are robust in the region, there are still problems with the ownership of banks which tends to expose the financial sector to systemic risk. Secondly, the financial system is open to negative shocks via falling share prices as banks have increased their exposure to equity markets. Finally, outside GCC countries, the MENA region's financial system seems to be the least connected to the real private sector in the entire world. Lending is to a select few, and on an average the region's businesses rely most heavily (75\%) on internally generated finance, compared to any other region of the world.

Table 13: Growth in Domestic Credit, 2001-2005

\begin{tabular}{lc}
\hline COUNTRY & PERCENTAGE GROWTH \\
& $2001-2005$ \\
\hline Egypt & 57.79 \\
Iran & 143.51 \\
Jordan & 76.24 \\
Saudi Arabia & 31.33 \\
United Arab & 154.71 \\
Emirates & \\
Syria & 40.96 \\
Lebanon & 26.49 \\
Algeria & -32.43 \\
Morocco & 24.93 \\
Tunisia & 33.18 \\
\hline \multicolumn{1}{c}{ Source: IMF, International Financial Statistics }
\end{tabular}

Source: IMF, International Financial Statistics

\section{$5 \quad$ Conclusions: Domestic Constraints on Growth}

In a nutshell, the recent economic history of the Middle East may be described as successful development despite modest growth rates compared to East and South Asia. Against this success, is the region's singular failure to diversify the production structure, and successfully climb the ladder towards higher value added manufactured exports, unlike in Asia. Middle Eastern countries, like most of Latin America, are middle income countries with higher wages than in Asia. 
They risk missing out on manufactured export led growth process, because they have never really exported labour intensive manufactures (unlike Asia) on a large enough scale, making the step towards the second (capital intensive) rung of the ladder more arduous for these latecomers to internationally competitive industrialization.

The region has several fuel/mineral exporting economies. With regard to the general difficulties faced by these types of economies, or the so called resource curse, three points stand out. First, the resource curse is a recent (post1970) phenomenon. Historically, an abundance of natural resource endowments has been a blessing and not a curse; see Murshed (2004) for a literature review. Secondly, there are macroeconomic mechanisms through which resource booms may adversely affect the economy. These emanate from an ephemeral spending effect (excessive consumption), and a relative price effect (real exchange rate appreciation and the domestic terms of trade moving in favour of non-traded goods). Thirdly, large resource rents may lead to the development of an adverse political economy, associated with an extractive or rentier state. It has to be emphasised, however, that all of these problems can be avoided within a good institutional setting, as the experience of Norway shows, and through judicious policy design leading to economic diversification, as the recent economic history of Malaysia illustrates. The resource curse may not be a curse at all, and the Dutch disease may not really be a disease if a wise and prudent course is followed. Indeed, there is some evidence to suggest that the resource curse in developing countries may be an artefact of the recent past (Metcalfe, 2007).

The MENA region certainly went through a boom and bust cycle, associated with the peak in oil prices during the very early 1980s, and there subsequent decline in the mid-1980s. Growth in per-capita income fell into negative territory for many of the region's economies, especially oil exporters during the 1980s, and the decline continued into the 1990s for many, although there was a recovery for others. The decline of the 1980s for major oil exporters had classic symptoms of Dutch Disease phenomenon associated with real exchange rate appreciation which persisted even after oil prices declined, combined with over-absorption and rising government spending which led to the accumulation of debt stocks. Other, non-oil based economies were in need of structural reforms to make their economies more open and many of these were subsequently implemented. Yet despite the growth slow down, poverty, where measured in the region, continued to decline. Not only that, but the region achieved a reduction in measured income inequality in contrast to high growth East Asia. At present it has low inequality, comparable to South and East Asia, and the lowest incidence of poverty for any part of the developing world outside Europe, which is a major achievement given that regional average per-capita income is below the Latin American average. Its achievements in health and 
education were also impressive, including that for female schooling despite the region's so-called Islamic anti-female orientation. Gradually, since the mid-1980s, the region's resource poor and labour abundant countries economic cycles became more decoupled from oil prices, as these economies came to rely less on worker remittances from the Gulf.

The recent oil boom has not produced profligacy. There is little evidence of Dutch Disease. Rather real exchange rates have not been allowed to appreciate despite improvements in the external terms of trade, the increase in consumption is less muted, there is less of an import surge, and the oil surpluses have been invested wisely including savings for future use, and investment inflows into the resource poor countries of the region. Above all, there is fiscal prudence this time around and oil exporting countries have been successful in substantially retiring stocks of national and external debt. Oil importing countries in the region have, however, been hit hard by the rise in oil prices both in terms of the balance of payments (partially offset by greater tourism and service exports), and on account of their domestic fuel subsidies.

In connection with medium-term policies to promote growth, Rodrik (2006) has proposed a diagnostic methodology for searching for the more binding constraints on growth. This manner of proceeding is predicated on the fact that institutions (which may affect long-term growth prospects) are slow to change, but policy makers cannot wait for fundamental institutional improvement before attempting to foster economic growth and poverty reduction. In this spirit, three broad constraints on growth in the region have been identified in the literature.

The first pertains to labour markets and unemployment. The MENA region is characterised by some of the highest rates of unemployment in the world, and it also has a high level of new entrants to the labour market (for example, 56\% of Saudis are aged below 20). The unemployment problem is particularly acute at present in Iraq, the Palestinian territories, Egypt, Algeria and Morocco. Countries in the region (except Jordan) have, however, lowered unemployment rates below what would be predicted by comparisons with the rest of the world of their growth in output per-worker (World Bank, 2006, figure 1.3). The greatest success has been in Algeria, Morocco and Iran, but also in Saudi Arabia. This is a good sign, but is related to the recent oil boom. This raises questions regarding the sustainability of the recent achievements in unemployment reduction. Murshed (2007) points out that the share of public sector wages and salaries in total government expenditure is disproportionately high in the MENA region compared to other parts of the developing world, East Asia say; large levels of public sector employment are less robustly sustainable in the long-run because of fiscal exigencies. A heavy dependence on oil does little to create employment, as oil is notoriously capital intensive. But more importantly, labour productivity needs to rise along with job creation. Improvements in this 
area require capital deepening and renewal, implying greater investment in manufacturing. Also, the quality of education and skill acquisition may require upgrading.

This brings us to the second growth constraining issue, related to the efficiency of the financial sector, and its role in providing productive investment. The degree of financial deepening is quite high in the region, so the base for investment finance appears to be present. The recent oil boom had led to increases in liquidity, growth in domestic credit (table 13), burgeoning stock markets and a real estate bubble. All of these post-2002 developments point to financial Dutch Disease symptoms. The ratio of market capitalization to GDP grew from $26 \%$ of GDP in 2002 to $110 \%$ in 2005 in the MENA on an average, with burgeoning new IPOs (initial public offerings). This is a sign of an overheated securities market, along with concomitant dangers to the real economy of negative financial sector shocks. The real value of bank deposits increased by about $15 \%$ in the MENA region between 2002 and 2005 (World Bank, 2006). Corresponding to that, there has also been a rise in the proportion of private sector credit to GDP. But this has not been a universal development; it is estimated that about $40 \%$ of the population have not benefited from this credit growth. It is noteworthy that use of internal finance (rather than bank credit) in the region's enterprises is the greatest in the world. This, however, means that the real effects of any financial sector shocks will be more muted, and indeed there is little evidence of banking crises in the region.

The third, and perhaps most important, constraint on growth pertains to the quality of bureaucratic regulation. Murshed (2007) points out the low proportion of manufactured exports in total exports for even most of the resource poor countries of the region. The two successes in this regard are Morocco and Tunisia. This can be contrasted to the experience of East and South Asian economies, where policies of competitive industrialization were pursued leading to growth in manufactured exports. Non-GCC MENA countries have not properly exploited any potential comparative advantage in (labour or slightly more capital intensive) manufactured exports. In failing to do so they have missed out on the lower rungs of the ladder defining stages of growth and development based on gradually increasing the value added of exports. Most of the region's oil exporting economies (except Algeria), and MENA as a whole, have negative real saving rates, once the rate of resource depletion is taken into account (Table 14). This makes economic diversification of paramount importance to future economic sustainability, looking forward to the time when oil and gas run out. In the ultimate analysis, this amounts to institutional quality and the structure within which policy is conducted. It has also been pointed out repeatedly that resource abundance can lead to the postponement or avoidance of necessary structural policy and institutional reforms. 
Table 14 Adjusted Saving Rates as a Percentage of GNI in 2004

\begin{tabular}{l|l}
\hline Algeria & 3.6 \\
\hline Egypt & 1.6 \\
\hline Iran & -5.6 \\
\hline Iraq & -6.2 \\
\hline Jordan & 13.5 \\
\hline Kuwait & -10.5 \\
\hline Lebanon & -9.3 \\
\hline Morocco & 22.3 \\
\hline Oman & -40.6 \\
\hline Saudi Arabia & -11.1 \\
\hline Syria & -28.4 \\
\hline Tunisia & 11.1 \\
\hline MENA & $-\mathbf{6 . 2}$ \\
\hline Sub-Saharan Africa & $\mathbf{- 1 . 9}$ \\
\hline South Asia & $\mathbf{1 2 . 4}$ \\
\hline East Asia & $\mathbf{2 3 . 9}$ \\
\hline Latin America and the Caribbean & $\mathbf{5 . 6}$ \\
\hline Developing Country Average & $\mathbf{9 . 4}$ \\
\hline $\begin{array}{l}\text { Source: WDI, 2006 } \\
\text { Note: The method involves adding education expenditure as a percentage } \\
\text { of national income to gross savings rates. Then, three items are deducted: } \\
\text { (a) capital depreciation rates, (b) the rate of natural resource depletion, (c) } \\
\text { and pollution costs. }\end{array}$ \\
\hline
\end{tabular}

The World Bank (2006) report contains indicators related to trade policy, the business climate and the quality of governance. These indicators are more related to the formation of expectations regarding the business environment in connection with investment in new and risky areas. The studies present both the current status of various indicators in the MENA, and the region as a whole, as well as the pace of reforms. Three factors stand out. First, the GCC countries are more open in terms of their trade policy. Egypt and Jordan have made considerable progress in this area, but much more structural reform in trade policies is needed in Syria. Secondly, there is room for improvement in the business climate, particularly in Egypt. For example, in Egypt, Enders (2007) examines the binding constraints on growth finding that financial sector inefficiencies, government red-tape and over-taxation of the corporate sector may be the real binding constraints, in addition to the non-sustainability of fiscal deficits. Thirdly, the weakest performance in the entire region is related to one particular area of governance, public sector accountability, and this requires the most improvement. By contrast, in the UAE the IMF (2005) points to the many successes associated with its open product and labour markets, as well as its 
highly developed infrastructure and business friendly policies. Of all GCC countries, it is the least oil dependent, and its non-oil GDP shows the highest average rate of growth (8\%) in the GCC since 1995.

The greatest external constraint to growth is the geo-political situation which adversely afflicts regional security along with multiple conflicts (Iraq, Lebanon, Palestine-Israel), and the possible slowdown in the global economy due to the global financial crises.

Unlike oil-rich countries in other parts of the developing world the region is remarkably stable. It has also managed to avoid greed driven civil war over resource rents and wars of secession over oil and gas rents (discounting Sudan), placing it at variance with other parts of the developing world. This implies the prevalence of a viable and working social contract in most parts of the region. In terms of governance, the indicators for government effectiveness, rule of law and regulatory quality are favourable by developing country standards, including high growth East Asia; indeed in terms of the control of corruption the region is ahead of East Asia. Its scores for democratic orientation are hampered by the infrequency of national multi-party elections. All in all, in spite of being rich in resources, the institutional and human development record of the region is superior to many parts of the developing world, especially compared to African resource rich economies, and epithets such as the alleged 'petromania' characterising social development in the Middle East are largely unjustified.

Despite widespread prejudice to the contrary, the cultural values of the region are not inimical to broad based development with equity. Gradstein, Milanovic and Ying (2001) show that across the diverse cultural/religious types in the world, there is the strongest built-in inequality aversion among Muslim majority countries. They find this, after controlling for per-capita income and democracy scores, which both tend to reduce inequality. They attribute this intrinsic inequality aversion to cultural features favouring redistribution in both Islamic and East Asian cultures (but more strongly in the former), which they argue promotes greater equality even when there is the absence of democratic political pressures favouring redistribution as in the Judeo-Christian world. ${ }^{7}$ They point to concern for the extended family as the factor responsible for this inequality aversion in Islamic and East Asian cultures. The neglected dimensions of various Islamic traditions and religious injunctions ${ }^{8}$ that foster private responsibility among the faithful regarding social issues such as poverty also need emphasizing in explaining the lower poverty and inequality outcomes in the MENA region and the Islamic world in general.

\footnotetext{
${ }^{7}$ Following this argument, there would be greater inequality in Judeo-Christian societies without democracy, as their intrinsic inequality aversion is lower.

${ }^{8}$ For the observant Muslim, Zakat or charitable giving described above is one of the five pillars or central tenets of the faith.
} 


\section{REFERENCES}

Acemoglu, Daron, Simon Johnson, and James Robinson (2005) 'Institutions as the Fundamental Cause of Long-Run Growth', in Philippe Aghion and Steven Durlauf (eds), Handbook of Economic Growth 1(1), Amsterdam: Elsevier, 385- 472.

Adams, Richard R and John Page (2003) 'Poverty, Inequality and Growth in Selected Middle East and North Africa Countries', World Development, 31(12), 2027- 2048.

Auty, Richard M (2001) 'A Growth Collapse with High Rent Point Resources: Saudi Arabia', in Richard M Auty (ed) Resource Abundance and Economic Development, Oxford: University Press, 193-207.

Auty, Richard M and Alan G Gelb (2001) 'Political Economy of Resource Abundant States' in Richard M Auty (ed) Resource Abundance and Economic Development, Oxford: University Press, 126-44.

Eifert, Benn, Alan Gelb and Nils Borje Talroth (2002) 'The Political Economy of Fiscal Policy and Economic Management in Oil Exporting Countries', Policy Research Working Paper 2899, World Bank.

Enders, Klaus (2007) 'Egypt-Searching for Binding Constraints on Growth', IMF Working Paper: WP/07/57.

ESCWA (2005) 'Analysis of Performance and Assessment of Growth and Productivity in the ESCWA Region', Economic and Social Commission for Western Asia, New York: United Nations.

Gradstein, Mark, Branko Milanovic and Yvonne Ying (2001) 'Democracy and Income Inequality: An Empirical Analysis’, World Bank Policy Research Paper no. 2561.

Hakura, Dalia S (2004) 'Growth in the Middle East and North Africa', IMF Working Paper, WP/04/56, Washington DC: IMF.

IMF, International Financial Statistics Data Base.

IMF (2005) United Arab Emirates: Selected Issues, Country Report No. 05/268, International Monetary Fund, Washington D.C. 
IMF (2006, 2008) World Economic and Financial Surveys, Regional Outlook for the Middle East and Central Asia, September 2006, International Monetary Fund, Washington D.C.

Iqbal, Farrukh (2006) Sustaining Gains in Poverty Reduction and Human Development in the Middle East and North Africa, Washington D.C.: World Bank.

Kakwani, Nanak and Edward Pernia (2000) 'What is Pro-Poor Growth', Asian Development Review, 16 (1), 1-16.

Kaufmann, Daniel, Aart Kraay and Massimo Mastruzzi (2006) 'Governance Matters V, Aggregate and Individual Governance Indicators for 19962005, World Bank, www.worldbank.org.

Kedourie, Elie (1992) Democracy and Arab Political Culture, Washington: Institute for Near East Policy.

Makdisi, Samir, Zeki Fattah and Imed Limam (2000) 'Determinants of Growth in the MENA Countries’, Arab Planning Institute Working Paper no. 03/01, Kuwait.

Metcalfe, Robert (2007) 'The Natural Resource Curse: An Unequivocal Hypothesis', mimeo, Imperial College, London.

Murshed, S Mansoob (2004) When Does Natural Resource Abundance Lead to a Resource Curse, IIED-EEP, Working Paper 04-01, www.iied.org.

Murshed, S. Mansoob (2006) 'Turning Swords into Ploughshares and Little Acorns to Tall Trees: The Conflict Growth Nexus and the Poverty of Nations', background paper for the United Nations-Department for Economic and Social Affairs' World Economic Survey, 2006, http://www.un.org/esa/policy/wess/.

Murshed, S. Mansoob (2007) 'Development Despite Modest Growth: Middle Eastern Economies in Perspective’, report to UN-ESCWA. 
Nabli, Mustapha Kamel and Marie-Ange Véganzonès-Varoudakis (2007) 'Reform Complementarities and Economic Growth in the Middle East and North Africa', Journal of International Development, 19 (1), 17-54.

Noland, Marcus (2008a) 'Explaining Middle Eastern Political Authoritarianism I: The Level of Democracy', Review of Middle Eastern Economics and Finance, 4(1).

Noland, Marcus (2008b) 'Explaining Middle Eastern Political Authoritarianism II: Liberalizing Transitions’, Review of Middle Eastern Economics and Finance, 4(1).

Polity IV Project (Center for International Development and Conflict Management), http://www.cidcm.umd.edu/polity.

Ravallion, Martin and Gaurav Datt (1991) 'Growth and Redistribution Components of Changes in Poverty Measures: A Decomposition with Applications to Brazil and India', Journal of Development Economics, 38 (2), 273-295.

Rawls, John (1999) The Law of Peoples, Cambridge, MA: Harvard University Press.

Rodrik, Dani (1999) 'Where Did All the Growth Go? External Shocks, Social Conflict, and Growth Collapses', Journal of Economic Growth, 4 (4), 385412.

Rodrik, Dani (2006) 'Goodbye Washington Consensus, Hello Washington Confusion', Journal of Economic Literature, 44 (4), 973-989.

Ross, Michael L. (2001) 'Does Oil Hinder Democracy', World Politics 53(3), 325-61.

Ross, Michael L. (2008) ‘Oil, Islam and Women’, American Political Science Review, 102(1), 107-123.

Sachs, Jeffrey D. and Andrew Warner (1995) 'Economic Reform and Process of Global Integration,’ Brookings Papers on Economic Activity, (1), 1-118. 
Sala-i-Martin, Xavier and Elsa V Artadi (2002) 'Economic Growth and Investment in the Arab World', Columbia University Department of Economics Discussion Paper No. 0203-08.

Saudi Arabian Monetary Authority (SAMA) Data Base http://www.sama.gov.sa/newreports/annual/en/section10/indexe.htm.

Srinivasan, Sharada and Arjun Singh Bedi (2008) 'Daughter Elimination in Tamil Nadu, India: A Tale of Two Ratios', Journal of Development Studies, 44 (7), 961-990.

Stewart, Frances (2008) 'Global Aspects and Implications of Horizontal Inequalities (HIs): Inequalities Experienced by Muslims Worldwide’, mimeo.

UNDP (2006) Human Development Report, New York: United Nations Development Program.

World Bank (2001) World Development Report, 2000/2001: Attacking Poverty, New York: Oxford University Press.

World Bank (2006) Economic Developments and Prospects, Financial Markets in a New Age of Oil, Middle East and North Africa Region, Washington D.C.: World Bank.

World Development Indicators (2006), Washington D.C: World Bank. 